\title{
Pre-Entry Doctoral Admission Variables and Retention at a Hispanic Serving Institution
}

\author{
Floralba Arbelo Marrero \\ Carlos Albizu University, Miami, Florida, USA
}

\author{
farbelo@albizu.edu
}

\begin{abstract}
Doctoral student retention remains a challenge in higher education with an average attrition rate of $50 \%$. This study focuses on analyzing pre-entry variables of admission for 81 doctoral students admitted to a doctoral program in psychology to determine whether significant associations existed between specific variables in the graduated and withdrawn groups in this cohort with over $48 \%$ Hispanic doctoral student representation. Using various quantitative analyses, findings demonstrate that the variables of GPA, ranking of ability, marital status, employment, and prerequisites completed prior to entry into the doctoral program are each indicators of success for doctoral students. Specifically, a higher GPA, a higher ranking of ability, single marital status, part-time versus full-time employment, and the more pre-requisites completed before entering a doctoral program indicate a higher likelihood of doctoral program completion. Findings can be used as markers in the admission process to develop support and curricular interventions that will sustain doctoral students throughout the course of their doctoral studies.
\end{abstract}

Keywords: Doctoral Student Retention, Hispanic Doctoral Students, Retention, Hispanic Serving Institutions, Attrition, Doctoral Completion, Quantitative, Pre-Entry Variables

\section{Introduction}

Among the pressing issues in higher education, the completion rates of doctoral students enrolled in graduate programs is of concern because of the substantial investment of funding, resources, and time by both students and institutions. Crucial areas of concern include student expenditures, debt incurred, stress, and lost professional career opportunities for students that desert or have been dismissed from their academic programs (Schneider \& Yin, 2011). The programmatic rating of institutions by accrediting agencies is negatively affected by several factors, including attrition rates, which impact accreditation cycles, or in some cases causes programs to lose accreditation.

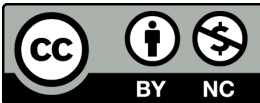

This article has been copyrighted by the Informing Science Institute on behalf of its authors. We license it to you under a Creative Commons AttributionNonCommercial 4.0 International License. When you copy and redistribute this paper in full or in part, you need to provide proper attribution to it to ensure that others can later locate this work (and to ensure that others do not accuse you of plagiarism). You may (and we encourage you to) adapt, remix, transform, and build upon the material for any non-commercial purposes. This license does not permit you to use this material for commercial purposes.
Programmatic rating is determined by the student loan default rates, attrition, quality of faculty, opportunities for research, and articulation agreements (Ampaw \& Jaeger, 2012; Bair \& Haworth, 2005; Wao \& Onwuegbuzi, 2011). Despite the rigorous selection process of doctoral students in higher education, as well as their portfolios which are comprised of: skills, intelligence, experiences, and value that students bring with them to a doctoral program, research has shown that upwards of $46 \%$ of doctoral candidates do not complete their programs (Bair \& Haworth, 2005; Grasso, Barry, \& Valentine, 2008; 
Spaulding \& Rockinson-Szapkiw, 2012). In fact, the Council of Graduate Schools (2008) asserted that only $41 \%$ of doctoral students complete their degrees within seven years and $57 \%$ between seven and ten years. Of course, these figures vary based upon student demographics and discipline of study; fields of study with the highest completion rates are engineering, medicine, law, and business (Council of Graduate Schools, 2008). Moreover, it is important to keep in mind that the emotional, financial, and career implications that are tied to attrition pose significant stressors that have an impact beyond the doctoral student that has deserted an academic program. Families and significant others are also affected by attrition. Doctoral attrition research has covered student factors that include demographic variables, student characteristics, motivation, coping mechanisms, social and academic integration, and finances, among others (Golde, 2005; Grover, 2007; Hoskins \& Goldberg, 2005; Lott, Gardner, \& Powers, 2009; Price, 2006; Terrel, Snyder, \& Dringus, 2009; Tinto, 1993; Torres \& Solberg, 2001; Wao \& Onwuegbuzie, 2011; Wasburn-Moses, 2008;). Attrition research has also included institutional characteristics related to doctoral program attrition including program structure, curriculum, communication, student expectations, and socialization within the program (Hoskins \& Goldberg, 2005; Lovitts, 2001; Wasburn-Moses, 2008).

\section{Literature Review}

This attrition problem has administrators and researchers across the United States struggling to understand how to decrease doctoral attrition and work through the repercussions associated with academic attrition to try to increase doctoral student retention. It is a fact that doctoral studies require a substantial commitment from the student (at least five to seven years' time) and some research shows that some students may be unaware of the demands that a doctoral program calls for (Golde \& Dore, 2001). In the area of psychology, research, internships, and licensure examinations are each a part of the completion process and can prove daunting for students that are not prepared for the rigors of these milestones in their programs (Graham \& Kim, 2011). Past research also shows that success in a doctoral program depends upon various factors that may be inter-related, such as academic preparation, age, work experience, type of program, previous research experience, type of institution, faculty- student relationships, and mentoring (Spaulding \& Rockinson-Szapkiw, 2012; Vilkinas, 2007; Wao \& Onwuegbuzie, 2011; Wasburn-Moses, 2008). Past doctoral attrition research has analyzed individual student characteristics such as financial ability to enroll in a doctoral program, academic and psychological preparedness, stress factors, ethnicity, race, and social integration (Jairam \& Kahl, 2012; Lovitts, 2001; Wao \& Onwuegbuzie, 2011). Doctoral attrition rates are often reported as overall figures, yet some believe that among minority and underrepresented groups, such as Hispanics, the doctoral attrition rate is higher (Lovitts, 2001). The Council of Graduate Schools asserts that among minority groups attrition is a more serious issue (2008). According to the National Center for Education Statistics (Aud et al., 2012) Hispanics represent only five percent of doctoral degrees earned across disciplines, making this group among the lowest to have earned this type of advanced degree (Aud et al., 2012). In the social sciences, where a significant amount of Hispanic doctoral students are enrolled, there is a $63 \%$ attrition rate for Hispanics (Council of Graduate Schools, 2008). The scant amount of literature on the subject of underrepresented groups at the doctoral level suggests that among this group, many represent first-generation students, come from low socioeconomic backgrounds, are less knowledgeable on how to negotiate graduate studies (Gardner, 2013), and may not have had exposure to prior research activities that could help them transition toward independent research (Lovitts, 2005). Previous research demonstrates that first generation Hispanic doctoral students experience feelings of isolation, marginalization, and perceive a sense of unworthiness from faculty and non-Hispanic peers and attribute this to their own ethnicity (Gonzalez et al., 2001; Solórzano, 1998). Furthermore, little research has been published on Hispanic doctoral students at Hispanic Serving Institutions (HSIs), which are becoming more common among higher education 
institutions due to population growth and geographic shifts among this group in the United States (Gardner, 2013; Vaquera, 2008). Hispanic Serving Institutions, higher education institutions that serve $25 \%$ or more of Hispanic undergraduate students, represent over 409 currently designated institutions in the United States representing $12.1 \%$ of all non-profit colleges and universities; these institutions enroll almost $60 \%$ of the Hispanic college going population. Among the HSIs in the United States, 66 offer doctoral degrees, and the majority of HSIs are concentrated in California, Florida, New Mexico, New York, and Texas; currently there are 296 emerging HSIs with a bourgeoning Hispanic population of $15-24 \%$ which broadens the scope of HSIs serving this population (Excelencia in Education, 2015). Due to the increasing role of HSIs in educating the Hispanic college going population, it is important for studies to be conducted among these institutions to help inform decision-making and practices that support Hispanic student success, especially at the graduate level where a dearth of research exists. Due to their low completion rates, doctoral programs are being forced to conduct self-assessments to understand the variables associated with attrition in order to adjust curriculum, admission policies, and program interventions that help sustain doctoral students to completion. As institutions struggle to understand how to increase student motivation or adjust programmatic variables to increase retention, it is important to review the doctoral student screening process and student characteristics, as well as previous academic experiences to assess whether these may be significant predictor variables that can be linked to successful completion of doctoral studies. These types of predictor variables may be assessed and monitored as a part of the admissions process and understood as risk factors for doctoral programs, allowing administrators and faculty to make sound decisions in programming, policies, and practices that do not compromise access for underrepresented populations but serve to provide insight to further support student success. In general, the high attrition rates among doctoral students warrant a look at pre-entry variables that may provide insight to applicants' success in graduate studies.

\section{Theoretical Framework}

Tinto (1993) developed a longitudinal doctoral persistence model that spans across various stages of the doctoral experience. The model "posits that individual attributes, most notably gender, age, race, ability, and social class, and individual educational experiences prior to graduate school" (Tinto, 1993, p. 239) help to establish the ability, attitude, and commitment that an individual student may possess upon entering a doctoral program. This model has asserted that students arrive at college with a set of characteristics and skills that determine conditions in which longer term interactions within an academic program will help determine academic persistence. Tinto (1993) acknowledges that student characteristics, previous educational experiences, and student background each influence the first phase of doctoral academic success; these pre-entry variables and experiences can play a significant role in setting the stage for long-term doctoral student success. Likewise, the external commitments of an individual student, such as family and employment, impact the ability of the student to engage in a doctoral program of study and may affect the academic persistence of that student. Students with competing roles and obligations find their time and efforts pulled in diverse directions and thereby find it challenging to meet academic obligations against stressors that may act as deterrents to academic persistence (Arbelo-Marrero \& Milacci, 2016). Tinto's (1993) model is applied to this study through the lens of pre-entry variables that are the pre-cursors of success for the individual student. These student characteristics interact over the long term with other aspects and systems of the institution in which they are enrolled, determining outcomes for the student. How well a student adapts, integrates, and continuously commits to the program of study can reinforce his or her persistence in an academic program. The purpose of this study is to examine whether student variables associated with student entry orientation to a doctoral program in psychology at a Hispanic Serving Institution with a Hispanic doctoral student population of over $48 \%$ can influence retention. This study will determine whether 
there is a significant link between the specific student characteristic variables of undergraduate GPA, graduate GPA (where applicable), age at time of admission, ranking of ability, marital status, employment status, and prerequisites fulfilled prior to admission and student retention. While there has been research using these variables to assess retention, a formal study on the group of the specific predictor variables mentioned here was not noted in the literature in one single study but some of the variables across various studies, and certainly not within a doctoral program with a Hispanic population of more than $48 \%$ at a Hispanic Serving Institution, which adds relevance to this research.

\section{Methods}

This study uses a quantitative methods design to analyze specific pre-entry student characteristics to determine their relationship to doctoral retention for a doctoral program in psychology. This study assessed pre-entry variables of 81 doctoral students who graduated from a doctoral psychology program (graduated group) or who withdrew (or were withdrawn) from the program (withdrawn group), to answer the research question: Are there specific student characteristics at time of admission that may help predict whether a student will complete a doctoral program? Several quantitative analyses were conducted to test the following hypotheses:

Hypothesis 1: Graduates of the program are more likely to have higher undergraduate and graduate GPA's at time of admission.

Hypothesis 2: Graduates of the program are more likely to have entered the program at a younger age then those that did not graduate.

Hypothesis 3: The better the rank of ability of a student the more likely he or she is to graduate from a doctoral program.

Hypothesis 4: Single students are more likely to graduate from a doctoral program than married students.

Hypothesis 5: Students that are employed part time are more likely to graduate from a doctoral program than students that are employed full time.

Hypothesis 6: The more prerequisites completed by the student prior to admission to the doctoral program, the more likely he or she is to complete the doctoral program.

Several quantitative analyses were performed to determine whether there existed a significant difference between the two groups: graduated group and withdrawn group. Type of analysis was determined by type of scale of the variable (ex. Nominal, Interval), the number of participants that qualified for each group, normality and parametric testing (Howell, 2011). Testing each set of the variables GPA, Age, Ranking of Ability, Marital Status, Employment Status, and Prerequisites to determine the type of analysis to conduct decreases the chances for error. A rating sheet was developed to collect data for each participant to include the following variables: demographic data, undergraduate GPA, graduate GPA (if applicable), ranking of ability, employment status, and prerequisites completed. Two raters were used to ensure inter-rater reliability and the consistency of variables identified across raters.

\section{Participant Descriptive Statistics}

Archival data were collected on 81 students admitted to a doctoral program in psychology for the fall semesters of 2005 and 2006 at a Hispanic Serving Institution in the Eastern region of the United States. Due to accreditation standards, there was a cap on the number of students admitted to this particular doctoral program. The specific cohorts were chosen in order to analyze data of students who had time to complete the program, as accreditation standards place a cap of seven years to complete this particular program of study. The doctoral program did not require GRE 
scores during that period, therefore this information was not available to include as a variable. The data collected was separated into two categories: graduated group and withdrawn group. Descriptive statistics showed that the sample was $84 \%$ female, $60 \%$ single (Figure 1), ranged in ages 20 to 56 years (graduated group $\mu=27.69, S D=5.64$; withdrawn group $\mu=31.38, S D=$ 9.47) (Figure 2), consisted of $72 \%$ minority students (Figure 3), and that $87 \%$ were employed at time of admission. The average undergraduate GPA for the graduated group was $\mu=3.54, S D=$ .23 ; the average undergraduate GPA for the withdrawn group was $\mu=3.28, S D=.25$.

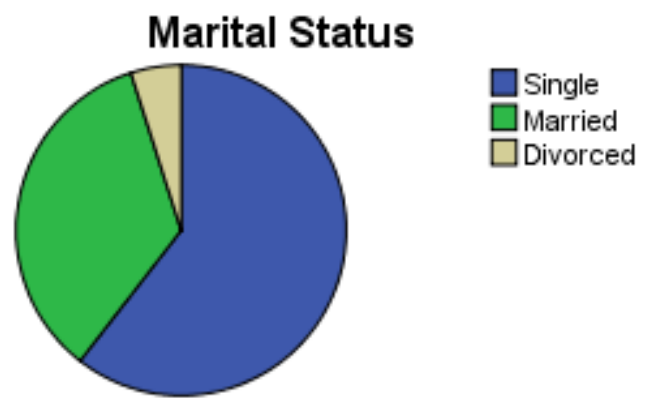

Figure 1. Marital Status Both Groups

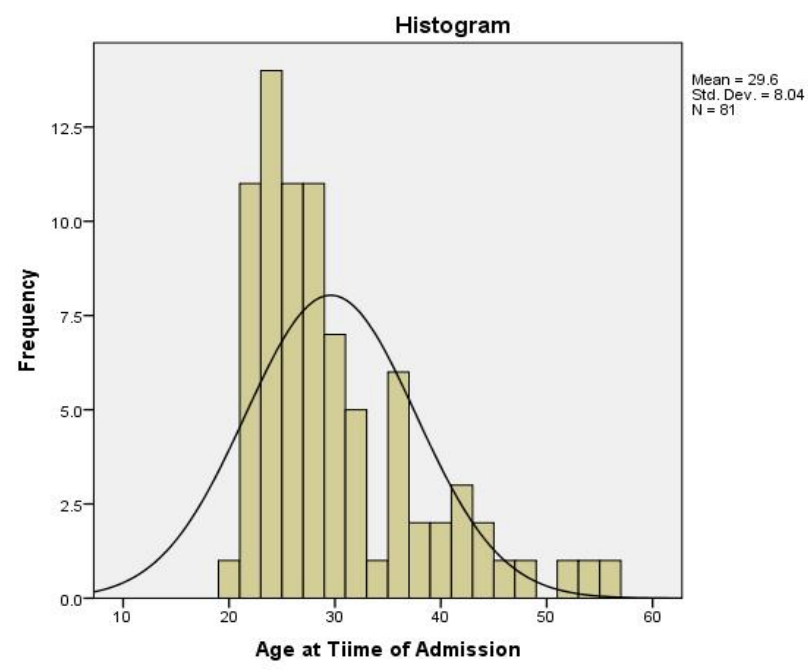

Figure 2. Average Age Both Groups $\mu=29.7$

\section{Race and Ethnicity}

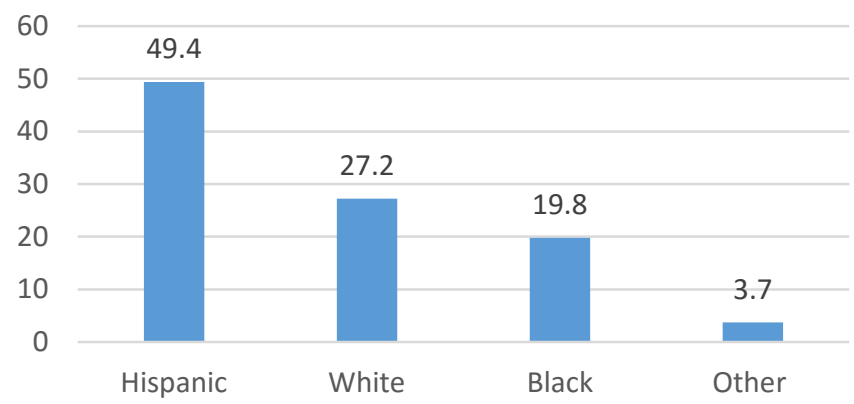

Figure 3. Race and Ethnicity of Both Groups 


\section{Materials and Procedures}

Data was collected from university archives through a de-identified rating system to protect the identity of cohort members. Information from rating forms was entered into the SPSS Version 22 statistical analysis system under specific variables for each group (graduated group, withdrawn group). Using SPSS for descriptive statistics, normality and homogeneity testing were also performed to determine if criteria satisfied for parametric analysis. These analyses revealed that Undergraduate GPA satisfied normality and homogeneity criteria (Sig. (p) $=.937>.05 ; n>30)$ for testing and an Independent t-Test was performed on the independent variable Undergraduate $G P A$ and dependent variable Status (graduate group, withdrawn group). Normality was satisfied for Age but it did not meet homogeneity criteria (Sig. $(\mathrm{p})=.001<.05)$. Normality was not satisfied for Graduate GPA and Ranking of Ability; therefore, a nonparametric Mann-Whitney U analysis was performed to determine whether Age, Graduate GPA, and Ranking of Ability demonstrated significant differences between the graduated group and the withdrawn group (Knapp, 2014). The variables of marital status, employment status, and prerequisites completed prior to admission represent nominal categorical variables that met the pretest checklist for number of individuals in each cohort and cell counts, and so a nonparametric Chi Square Analysis was performed to determine a correlation between each variable and the graduate group or withdrawn group (Knapp, 2014)

\section{Results and Discussion}

\section{Undergraduate and graduate GPA}

Is undergraduate GPA an indicator of success for doctoral students? An Independent t-Test identified a significant statistical difference in Undergraduate GPA $(\mathrm{p}=.000$ for $\alpha=.05)$ between the graduated group $(\mathrm{n}=39, \mu=3.54)$ and the withdrawn group $(\mathrm{n}=42, \mu=3.28)$ (Table 1$)$.

Table 1. t-Test for Undergraduate GPA and Graduation Status

\begin{tabular}{|c|c|c|c|c|c|c|c|c|c|}
\hline \multirow{2}{*}{$\begin{array}{l}\text { Confidence } \\
\text { Interval of Diff. }\end{array}$} & \multicolumn{2}{|c|}{$\mathrm{F}$} & ig. & $\mathrm{t}$ & $\mathrm{df}$ & Sig. (2 tailed) & \multicolumn{2}{|l|}{ Mean Diff. } & \multirow[t]{2}{*}{$95 \%$} \\
\hline & & & & & & & & & \\
\hline Undergraduate GPA & & & & & & & & Lower & Upper \\
\hline $\begin{array}{l}\text { Equal Variances As- } \\
\text { sumed }\end{array}$ & .109 & .742 & 3.517 & 79 & .001 & .24874 & .07073 & .10795 & .38952 \\
\hline Undergraduate GPA & & & & & & & & & \\
\hline $\begin{array}{l}\text { Equal Variances not } \\
\text { Assumed }\end{array}$ & & & 3.525 & 78.99 & .001 & .24874 & .07056 & .10829 & .38918 \\
\hline
\end{tabular}

Does possessing a higher graduate GPA indicate success in completing a doctoral program? As noted in Table 2 having a higher graduate GPA prior to admission did make a difference for those that completed the doctoral program $(U=84.5 ; p=.000$ for $\alpha=.05)$. 
Table 2. Graduate GPA and Doctoral Completion

\begin{tabular}{|l|r|}
\hline Mann -Whitney U & 84.5 \\
\hline Wilcoxon W & 384.5 \\
\hline Z & -3.516 \\
\hline Asymptotic Sig. (2 tailed) & .000 \\
\hline
\end{tabular}

The results show significant differences between the graduated group $(\mathrm{n}=19, \mu=3.72)$ and the withdrawn group $(\mathrm{n}=24, \mu=3.49)$. These findings were supported by Wao and Onwuegbuzi (2011) whose research demonstrated that a master degree grade point average was positively correlated to doctoral degree completion. Overall, previous research is conflicted on the association between grade point average and a student's ability to persist to degree completion (Ampaw \& Jaeger, 2012; Darolia, Potochnick, \& Menifeld, 2014). Some scholars have found that grade point average was not a significant predictor of degree completion, while others cited that completers and non-completers had similar grade point averages (Lovitts, 2001; Pyke \& Sheridan, 1993).

However, some research has asserted that grade point average was positively correlated to degree completion at the graduate level of study (Alvarez-Montero, Mojardin-Heraldez, \& AudeloLopez, 2014; Halberstam \& Redstone, 2005; Leavitt, Lombard, \& Morris, 2011; Lovitts, 2005; Menifield et al., 2007). Findings from this study affirmed that grade point average was an indicator of success in the completion of a degree program. Specifically, this research found a significant difference in grade point average between students that completed the doctoral program and students that did not complete the doctoral program, indicating that even a slightly higher GPA can act as a predictor for doctoral student success. In this case a .26 difference existed between the means of both groups at the undergraduate level and a difference of .29 existed between the means of two groups at the graduate level; in both instances the graduated group had a slightly higher GPA. This finding can inform administrators that are determined to honor access for minority students in the graduate pipeline by helping to form policy and curricular frameworks that help struggling students to successfully navigate the academic rigor of doctoral programs.

\section{Age}

Is age at time of admission a significant factor in the completion of a doctoral program? MannWhitney $U$ analysis demonstrated that age at time of admission to the doctoral program was not significantly different between the groups $(U=965.5 ; p=.165$ for $\alpha=.05)$ (Table 3$)$. On average for this population there was a slight difference between the means of the groups; the withdrawn group was older than the graduated group, with mean ages of 31.28 and 27.69 respectively.

Table 3. Age and Doctoral Completion

\begin{tabular}{|l|r|}
\hline Mann Whitney U & 965.5 \\
\hline Wilcoxon W & $1,868.50$ \\
\hline$Z$ & 1.388 \\
\hline Asymptotic (2 tailed) & .165 \\
\hline
\end{tabular}

This was not a significant finding. Previous studies validated this non-significant finding, determining that age was not a statistically significant variable between doctoral completers and non- 
completers (Dunnerstick, 1990; Quinn, 1991; Valentine, 1986, 1987). Yet increasingly applicants to graduate programs are on average older and more diverse; this change in the applicant pool requires programs to examine their admission criteria to reflect the evaluation of a changing applicant population (Darolia et al., 2014). In this study, the average age of the graduated group at time of admission was almost 28 years of age; this varies from the student that completes undergraduate studies and moves immediately into graduate school. Older students pose different challenges for graduate programs because other factors need to be considered when working with older students, including competing obligations, employment, and an academic gap between undergraduate studies and graduate studies.

\section{Ranking of Ability}

Is ranking of ability an indicator for student completion of the doctoral program? A Mann Whitney $\mathrm{U}$ found ranking of ability to be statistically and significantly different between the graduated group $(\mathrm{n}=39, \mathrm{p}=.000$ for $\alpha=.05, \mu=5.48)$ and the withdrawn group $(\mathrm{n}=42, \mu=12.13)$. This indicated a difference in the average rank of the graduated group and the withdrawn group (Table 4).

Table 4: Ranking of Ability and Doctoral Completion

\begin{tabular}{|l|r|}
\hline Mann Whitney U & $1,409.000$ \\
\hline Wilcoxon W & $2,312.00$ \\
\hline$Z$ & 5.601 \\
\hline Asymptotic Sig. (2 tailed) & .000 \\
\hline
\end{tabular}

In this study the individual recommending the student to the program ranks the student at the top $2 \%, 5 \%, 10 \%$ or $25 \%$, as compared to other students the recommender has worked with in the past. Therefore, a $\mu=5.48$ for the graduated group verses a $\mu=12.13$ for the withdrawn group indicated that the lower the rank the more likely the student is to graduate (students ranked in the top $25 \%$, top $10 \%$, top $5 \%$, top $2 \%$ in their academic abilities). Ranking of ability is classified in the literature as rating the ability of a graduate student to perform in a graduate program as compared to other graduate students under the letter of recommendation classification (Kuncel, Kochevear, \& Ones, 2014). In this particular doctoral program each applicant was evaluated using a rating form to be filled out by a former faculty member. Three ratings forms were required for each applicant, along with a general letter of recommendation. The rating form asked specific questions about a student's ability for oral expression, written expression, academic performance, collaborative abilities, commitment to endeavors, and potential for research, among others. Based upon the findings there was a statistically significant difference between ranking of student ability and outcomes (withdrawn, graduate). Almost all graduate programs utilize the letter of recommendation as a predictor of student performance, but not all doctoral programs annexed a rating form for the recommenders to fill out that allowed them to rank student abilities. Prior research has shown that at the graduate level, letters of recommendation and ratings are more reliable because they tend to come from previous professors that have had some academic experience with the applicant; this increases the validity of their evaluation of a candidate's academic performance. More recently, studies showing some promise for the letter of recommendation have suggested that letters of recommendation should focus on assessments of skill sets associated with graduate coursework, student motivation, and persistence, since these factors have been found to be more effective in appropriately assessing a student's ability to succeed in graduate coursework (Kuncel, Kochevar, \& Ones, 2014). 


\section{Marital Status}

Does marital status affect the likelihood of graduation? Pearson Chi-Square analysis yielded a statistically significant association between marital status and academic success between the graduated group ( $\operatorname{single~} \mathrm{n}=31$, married $\mathrm{n}=6)\left(x^{2}=.002\right.$ for $\left.\alpha=.05\right)$ and withdrawn group (single $\mathrm{n}=18$; married $\mathrm{n}=22$ ) $($ Table 5 ).

Table 5. Chi Square Analysis Marital Status and Doctoral Completion

\begin{tabular}{|l|l|l|c|}
\hline & Value & df & Asymp. Sig (2 sides) \\
\hline Pearson Chi Square & 12.498 & 2 & .002 \\
\hline Likelihood Ratio & 13.099 & 2 & .001 \\
\hline Linear by Linear Association & 7.598 & 1 & .006 \\
\hline N of Valid Cases & 77 & & \\
\hline
\end{tabular}

Past research has demonstrated mixed results for marital status and degree completion; in fact, earlier studies have indicated that marital status was not statistically linked to attrition or completion (Franklin, 1971; Girves \& Wemmerus, 1988). Yet other studies concluded that being a single student increased the likelihood of doctoral study completion (Hagedorn, 1993). Recent research has pointed toward an expected increase in a nontraditional student population enrolling in graduate programs as the trend has been established among undergraduate level enrollees (Council of Graduate Schools in the United States, 2009; Pappas \& Jerman, 2011). This is a reality that programs will have to take into account as they profile their doctoral student applicant pool; overall single students may experience less stress related to family and relationships than married students. It has been noted that the commitment to graduate study does impact the stability of the family because the requirements of doctoral programs are beyond that of a work day and that married doctoral students experience marriage stress because the demands of graduate school conflict with the responsibilities and benefits of marriage, creating significant stress for the student (Brannock, Litten, \& Smith, 2000). Today, more than ever, the nontraditional student has broken stereotypical barriers. Increasingly these are enrolling in doctoral programs of study; and as such, policies and practices need to reflect this population of students. Married doctoral students should comprehend the level of commitment and sacrifice that is required in pursuing a doctoral degree and help their family members realize the same. Family members must be willing to assume multiple responsibilities and a possible change of roles, during the doctoral student's time in the program. Research has concluded that married graduate students most frequently reported that the stressors associated with marriage and graduate school impacted their quality of family life, specifically the limited time and energy students have to expend on their families (Sori, Wetchler, Ray, \& Niedner, 1996). Married doctoral students are being supported by their families, and their inability to fully participate in the everyday responsibilities of the family causes stressors that can negatively impact their ability to complete a graduate program. Students that do not have these types of responsibility are spared the stressors associated with marriage during their course of study.

\section{Employment}

Does being employed affect the likelihood of graduation? Pearson Chi-Square analysis yielded a statistically significant relationship in employment between the graduated group $\left(x^{2}=.000\right.$ for $\alpha$ $=.05$ ) and the withdrawn group, indicating that students with part-time employment were more likely to graduate than students that were employed full- time (Table 6). 
Table 6. Employment Status and Doctoral Completion

\begin{tabular}{|l|l|l|c|}
\hline & Value & df & Asymp. Sig (2 sides) \\
\hline Pearson Chi Square & 19.425 & 2 & .000 \\
\hline Likelihood Ratio & 20.469 & 2 & .000 \\
\hline Linear by Linear Association & 13.643 & 1 & .000 \\
\hline N of Valid Cases & 81 & & \\
\hline
\end{tabular}

For this study, the majority of students were employed either full- or part-time while enrolled in their courses of study. Past research has demonstrated that finances do cause significant stress on graduate students and that many students do work to allay the strain of full-time study (Heins, 1984). Financial support and time to degree completion are negatively associated in doctoral studies (Solway, 1985). Ehrenberg and Sherman (1985) found that students who worked part time, that is, less than 25 hours each week, took longer to graduate than their peers who were not employed, but their grade point average did not suffer. Ehrenberg and Sherman (1985) also found that employment off campus tended to impact academic persistence more negatively than employment on campus. This has implications for the need to ease students' financial burdens by offering teaching assistantships and fellowships to graduate students to support their academic persistence by keeping them on campus. Programs can also provide financial information on fellowships, grants, and scholarships available to doctoral students. Nevertheless, for this cohort of students, working part time demonstrated a stronger correlation with degree completion than working full-time. The reality that many doctoral students, especially minority students, will work to offset the costs associated with studying and supporting themselves is a reality that programs must consider in their design. Support for working students can also be addressed through the development of hybrid course experiences, access to pre-recorded lectures, strong virtual libraries, the use of videoconferencing techniques to improve flexibility for students, and creating a more flexible environment that supports retention.

\section{Number of Prerequisites Completed Prior to Admission}

Does completing more prerequisites increase the likelihood of graduating from the doctoral program? The number of prerequisites completed prior to admission showed a statistically significant relationship between the graduated group and withdrawn group (Chi Square analysis $x^{2} \mathrm{p}=.001$ for $\alpha=.05$ ) (Table 7), which indicated that the more prerequisites completed by the student prior to admission, the higher the likelihood that they would graduate from the program (Figure 4).

Table 7. Number of Prerequisites Completed and Doctoral Completion

\begin{tabular}{|l|l|l|r|}
\hline & Value & df & Asymp. Sig (2 sided) \\
\hline Pearson Chi Square & 17.166 & 3 & .001 \\
\hline Likelihood Ratio & 18.140 & 3 & .000 \\
\hline Linear by Linear Association & 9.772 & 1 & .002 \\
\hline N of Valid Cases & 81 & & \\
\hline
\end{tabular}

This finding was supported by past research that demonstrated students who did not meet prerequisite requirements for academic degrees were underprepared for the rigors of the academic work 
required for them in their degree program; this was found to compromise their success (Soria \& Mumpower, 2012). Prerequisites are generally justified because they increase the student's chances of success in subsequent and more challenging courses; poorly constructed curriculum prerequisite courses can lead to poor performance, high withdrawal rates, and possible academic desertion (Abou-Sayf, 2008). Doctoral programs can use this information to encourage students to complete specific prerequisites before entering their programs, thereby increasing doctoral student success.

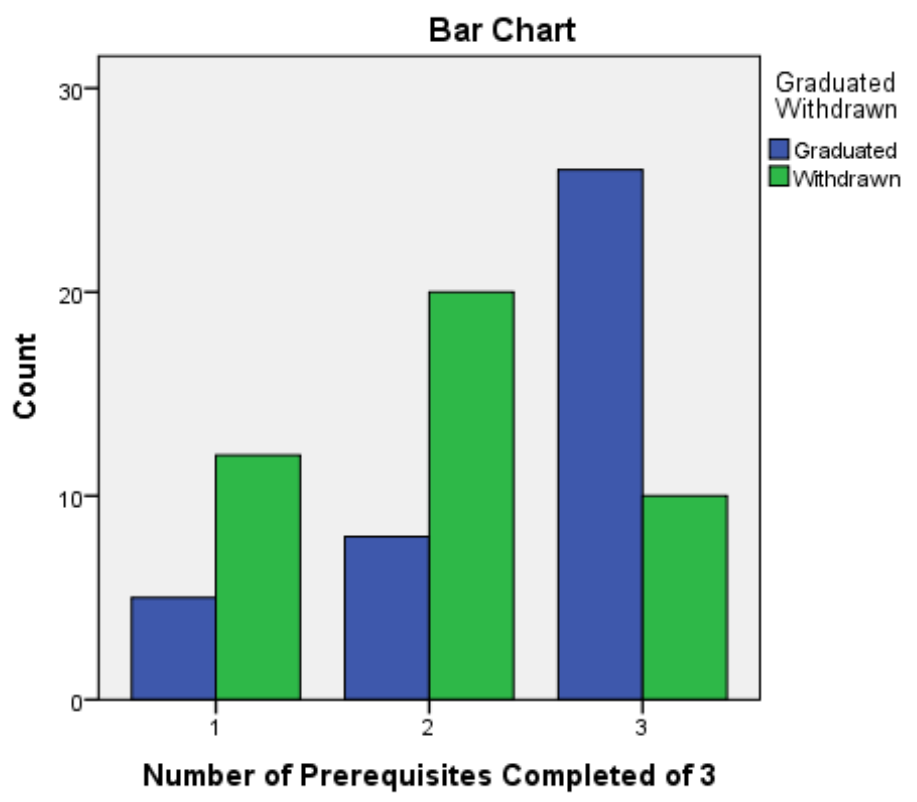

Figure 4. Prerequisites Completed Graduated and Withdrawn Groups

\section{Conclusion}

Doctoral programs are seeking to increase their levels of retention through efficient practices that will increase their completion rates, especially among minority students. This study assessed whether specific student characteristics at the admissions phase of a doctoral program at a Hispanic Serving Institution with a 48\% Hispanic doctoral student population were associated with student completion of that program. The analysis found significant associations between completion of the doctoral program and the variables of undergraduate and graduate GPA, ranking of ability, marital status, part time employment, and number of prerequisites completed. Each was found to be statistically significant in relation to the graduated group of the doctoral cohort. The findings of this study reinforce previous research on admission predictor variables for retention and affirm that personal characteristics are important in the doctoral student completion process (Brannock, Litten, \& Smith, 2000; Council of Graduate Schools, 2008; Dunnerstick, 1990; Grover, 2007; Price, 2006; Terrel et al., 2009; Tinto, 1993; Torres \& Solberg, 2001; Wao \& Onwuegbuzie, 2011; Wasburn-Moses, 2008). Yet for those in higher education that are interested in honoring access policies that support minorities through the doctoral study pipeline, these findings demonstrate that there is work yet to be done. While the variables assessed here can help advise admission committees, program faculty, and administrators of the potential that students bring with them from the onset, other research asserts that support from faculty, advisors, and student services also impact doctoral retention. It is important to keep both admission characteristics and institutional characteristics in the retention formula as each phase of the doctoral journey requires targeted and specific student skills and institutional support (Tinto, 1993). Many Hispan- 
ic doctoral students are first generation with no prior family history of graduate study or experience in research; this is an issue that faculty and administrators must acknowledge and work with at the program level (Gibbons \& Woodside, 2014; Gonzalez et. al, 2001). These students may perceive that they are as not as knowledgeable as their peers, which negatively affects their sense of belonging and confidence to complete their programs (Gardner, 2013). This lack of confidence can be ameliorated through faculty and peer mentor networks developed within a doctoral program to provide support in navigating doctoral experiences, coursework, and institutional academic support on demand (Spaulding \& Rockinson-Szapkiw, 2012). Therefore, setting up social networks within virtual applications that allow pages and information to be stored and accessed through groups is an excellent example of funds of knowledge that can be developed and accessible for students; this provides students with a sense of belonging and support through their academic process (Arbelo-Marrero, 2013). Within an institutional pipeline, faculty and administrators can co-labor to strengthen academic preparation for graduate school by improving curriculum such as writing for research courses, providing undergraduate students access to faculty research labs, ensuring that work-study experiences are less administrative, and providing more research related activities to begin early engagement in developing an academic mindset based on experience (Plunkett, Saetermoe, \& Quilici, 2014). Individuals who seek doctoral degrees do so because they desire professional advancement and institutions are accountable to their student bodies, accreditation agencies, faculty, and other tertiary stakeholders in higher education. While grade point average, ranking of ability, marital status, and employment may be important at the onset of a program, access for potential Hispanic doctoral students should also be considered at the admissions level. Underrepresented at the doctoral level, many Hispanic students do not have a framework of academia from which to draw, may arrive lacking some skill sets that can set them back from the onset of their coursework, and may experience feelings of isolation in their programs. This is why Hispanic Serving Institutions are positioned to prepare Hispanic students for doctoral careers. Those HSIs that do have doctoral programs have the potential to develop a climate of success that engages Hispanic doctoral students at each stage of their journey through specific and targeted experiences and services that support their success. At the undergraduate level, HSIs can improve undergraduate curriculum that will prepare students for the doctoral pipeline. At the doctoral level, HSIs can enhance their academic environments by hiring Hispanic faculty that mirror the population and thereby help diminish barriers of identity for their students. This will increase the role of the mentor advisor and develop a consistent model of mentor engagement across faculty so that they can be effective in their work with Hispanic students. Allowing students to develop intellectually by providing access to research labs, assistantships, academic roundtables, and seminars helps to cultivate the academic research skills that encourages doctoral student persistence (Vaquera, 2008). Some argue that many qualified students desert their academic programs for a number of reasons and that attrition is not always synonymous with being academically weak (Golde, 2005; Lovitts, 2001). Among the Hispanic population this holds true and this is why these pre-entry admission characteristics should not act as barriers to admission but serve to inform, support, develop strategies, and services that can positively impact doctoral student completion. Future research should focus on Hispanic faculty mentoring relationships with Hispanic doctoral students, the role of Hispanic faculty in the retention of Hispanic doctoral students, the role of acculturation for diverse groups of Hispanic doctoral students in the doctoral attainment process, and the value proposition of the doctorate for Hispanic students.

\section{Limitations and Future Research}

This study focused on the pre-phase stage of doctoral study, analyzing pre-entry variables of doctoral students, limited to only aspect of the doctoral experience. Other studies might consider variables during the second and third phases which include coursework experiences, relationships with faculty, and the dissertation process. Another limitation is that this study used data from two 
cohorts, a look at five or six consecutive cohorts may draw more robust information. Furthermore, this study focused on a single program which may also limit the generalizability of findings to other programs. Nevertheless, the study provides insight for doctoral programs that work with minority groups which is relevant for the current climate in higher education.

\section{References}

Abou-Sayf, F. (2008). Does the elimination of prerequisites affect enrollment and success? Community College Review, 36(1), 47-62.

Alvarez-Montero, F., Mojardin-Heraldez, A., \& Audelo-Lopez, C. (2014). Criteria and instruments for doctoral program admissions. Electronic Journal of Research in Educational Psychology, 12(3), 853-886.

Ampaw, F. D., \& Jaeger, A. J. (2012). Completing the three stages of doctoral education: An event history analysis. Research in Higher Education, 53, 640-660.

Arbelo-Marrero, F. (2013). Exploring factors that contribute to academic persistence for under graduate hispanic nontraditional students at Hispanic serving institutions in the Southeast (Doctoral Dissertation). Retrieved from http://digitalcommons.liberty.edu/doctoral/759

Arbelo-Marrero, F., \& Milacci, F. (2016). A phenomenological investigation of the academic persistence of undergraduate Hispanic nontraditional students at Hispanic Serving Institutions. Journal of Hispanic Higher Education, 15(1), 22-40. doi: 10:1177/1538192715584192.

Aud, S., Hussar, W., Johnson, F., Kena, G., Roth, E., Manning, E., Wang, X., \& Zhang, J. (2012). The condition of education 2012 (NCES 2012-045). U.S. Department of Education, National Center for Education Statistics. Washington, DC. Retrieved from http://nces.ed.gov/pubsearch

Bair, C., \& Haworth, J. (2005, November). Doctoral student attrition and persistence: A meta-synthesis of research. Paper presented at the ASHE meeting, San Antonio, TX.

Brannock, R. G., Litten, M. J., \& Smith, J. (2000). The impact of doctoral study on marriage satisfaction. Journal of College Counseling, 3, 123-130.

Council of Graduate Schools in the United States. (2008). CGS task force report on the professional doctorate. Washington, D.C.: Council of Graduate Schools. Retrieved from http://cgsnet.org/task-forcereport-professional-doctorate

Council of Graduate Schools in the United States (2009). Data sources: Nontraditional students, in graduate education. Research Report. Retrieved from www.cgsnet.org/ckfinder/userfiles/files/DataSources_2009_12.pdf

Darolia, R., Potochnick, S., \& Menifield, C. E. (2014). Assessing admission criteria for early and midcareer students: Evidence from a U.S. MPA program. Education Policy Analysis Archives, 22(101), 121.

Dunnerstick, R. (1990). Do admission criteria to the doctor of education in educational administration program predict completion? (Doctoral dissertation, University of Akron, 1990). Dissertation Abstracts International, 51(01A).

Ehrenberg, R. G., \& Sherman, D. R. (1985). Employment while in college, academic achievement and postcollege outcomes: A summary of results (Working Paper 1742). Retrieved from the National Bureau of Economic Research website: www.nber.org/papers/w1742

Excelencia in Education. (2015). The condition of Latinos in education: 2015 factbook. Washington, D.C.: Excelencia in Education. Retrieved from http://www.luminafoundation.org/files/resources/thecondition-of-latinos-in-ed.pdf

Franklin, J. B. (1971). Attrition and success of doctoral students in education administration at Arizona State University (Doctoral Dissertation). Dissertation Abstracts International: 31, 3180A.

Gardner, S. K. (2013). The challenges of first-generation doctoral students. New Directions for Higher Education, 163, 43-54. 
Gibbons, M. M., \& Woodside, M. (2014). Addressing the needs of first generation college students: Lessons learned from adults from low education families. Journal of College Counseling, 17, 21 -36.

Girves, J. E., \& Wemmerus, V. (1988). Developing models of graduate student degree progress. Journal of Higher Education, 59(2), 163-189.

Golde, C. M. (2005). The role of the department and discipline in doctoral student attrition: Lessons from four departments. Journal of Higher Education, 23, 199 - 227.

Golde, C. M., \& Dore, T. M. (2001). At cross purposes: What the experiences of doctoral students reveal about doctoral education. The Survey on Doctoral Research. Retrieved from http://www.phdcompletion.org/promising/golde.pdf

Gonzalez, K. P., Marin, P., Perez, L. X., Figueroa, M. A., Morenao, J. F., \& Navia, C. N. (2001). Understanding the nature and context of Latina/o doctoral student experiences. Journal of College Student Development, 42(6), 563-580.

Graham, J. M., \& Kim, Y. H. (2011). Predictors of doctoral student success in professional psychology: Characteristics of students, programs, and universities. Journal of Clinical Psychology, 67(4), 340-354.

Grasso, M., Barry, M., \& Valentine, T. (2007). A data driven approach to improving doctoral completion (Occasional Paper). Washington, DC: Council of Graduate Schools.

Grover, V. (2007). Successfully navigating the stages of doctoral study. International Journal of Doctoral Studies, 2, 9-21. Retrieved from http://www.ijds.org/Volume2/IJDSv2p009-021Grover21.pdf

Hagedorn, L. S. (1993, November). Graduate retention: An investigation of factors relating to older female graduate students. Paper presented at the annual meeting of the Association for the Study of Higher Education, Pittsburgh, PA.

Halberstam, B., \& Redstone, F. (2005). The predictive value of admissions materials on objective and subjective measures of graduate school performance in speech-language pathology. Journal of Higher Education Policy \& Management, 27(2), 261-272.

Heins, M. (1984). Perceived stress in medical, law, and graduate students. Journal of Medical Education, $59,169-179$.

Hoskins, C. M., \& Goldberg, A. D. (2005). Doctoral student persistence in counselor education programs: Student program match. Counselor Education and Supervision, 44(3), 175-188.

Howell, D. C. (2011). Fundamental statistics for the behavioral sciences (7th ed.). Wadsworth Cengage Learning: Belmont, CA.

Jairam, D., \& Kahl, D. H., Jr. (2012). Navigating the doctoral experience: The role of social support in the successful degree completion. International Journal of Doctoral Studies, 7, $311-329$. Retrieved from http://ijds.org/Volume7/IJDSv7p311-329Jairam0369.pdf

Kuncel, N. R., Kochevar, R. J., \& Ones, D. S. (2014).A meta-analysis of letters of recommendation in college and graduate admissions: Reasons for hope. International Journal of Selection and Assessment, 22(1), 101-106.

Knapp, H. (2014). Introductory statistics using SPSS. Sage Publications: Los Angeles, CA.

Leavitt, W. M., Lombard, J. R., \& Morris, J. C. (2011). Examining admission factors in an MPA program. Journal of Public Affairs Education, 17(3), 447-460.

Lott, J. L., Gardner, S., \& Powers, D. A. (2009). Doctoral student attrition in the Stem fields: An exploratory event history analysis. Journal of College Student Retention: Research, Theory \& Practice, 11(2), 247-266.

Lovitts, B. E. (2001). Leaving the ivory tower. Lanham, MD: Rowman \& Littlefield Publishers, Inc.

Lovitts, B. E. (2005). Being a good course taker is not enough: A theoretical perspective on the transition to independent research. Studies in Higher Education, 30(2), 137-154. 
Menifield, C. E., Clay, J., Carruth, J. R., Cheever, K., Norris-Tirrell, D., \& Roberts, G. (2007). Waiving the MPA entrance exam: Impact on performance. Journal of Public Affairs Education, 13(2), 403-424.

Pappas, J. P., \& Jerman, J. (2011), Editors' notes. New Directions for Adult and Continuing Education, 2011, 1-5. doi:10.1002/ace.395

Plunkett, S. W., Saetermoe, C. L., \& Quilici, J. L. (2014). Increasing the chances that underrepresented students will enter doctoral programs in mental health. Council on Undergraduate Research Quarterly, $1,36-41$.

Price, J. (2006). Does a spouse slow you down: Marriage and graduate student outcomes. Unpublished manuscript. Cornell University. Retrieved from http://digitalcommons.ilr.cornell.edu/workpapers/147/

Pyke, S. W., \& Sheridan, P. M. (1993). Logisitic regression analysis of graduate student retention. Canadian Journal of Higher Education, 23, 44-64.

Quinn, E. L. C. (1991). Doctoral student retention and selected personal factors (Doctoral dissertation, University of Southern Mississippi). Dissertation Abstracts International, 52 (09A).

Schneider, M., \& Yin, L. (2011). The high cost of low graduation rates: How much does dropping out of college really cost? Washington DC: American Institutes for Research. Retrieved from http://www.air.org/sites/default/files/download/AIR High_Cost of_Low_Graduation_ug 2011 0.pdf

Solórzano, D. (1998). Critical race theory, racial and gender microaggressions, and the experiences of Chicana and Chicano scholars. International Journal of Qualitative Studies in Education, 11, 121- 136.

Solway, K. S. (1985). Transition from graduate school to internship: A potential crisis. Professional Psychology: Research and Practice, 16, 50-54.

Sori, C. F., Welcher, J. L., Ray, R. E., \& Niedner, D. M. (1996). The impact of marriage and family therapy graduate training programs on married students and their families. The American Journal of Family Therapy, 24, 259-268.

Soria, K. M., \& Mumpower, L. (2012). Critical building blocks: Mandatory prerequisite registration systems and student success. NACADA Journal, 32(1), 30-42.

Spaulding, L. S., \& Rockinson-Szapkiw, A. J. (2012). Hearing their voices: Factors of doctoral candidates attribute to their persistence. International Journal of Doctoral Studies, 7, 199-219. Retrieved from http://ijds.org/Volume7/IJDSv7p199-219Spaulding334.pdf

Terrel, S. R., Snyder, M. M., \& Dringus, L., P. (2009). The developmental, validation, and application of the doctoral student connectedness scale. The Internet and Higher Education, 5(4), 345-352.

Tinto, V. (1993). Leaving college: Rethinking the causes and cures of student attrition (2nd ed.). Chicago: The University of Chicago Press.

Torres, J. B., \& Solberg, V. S. (2001). Role of self-efficacy, stress, social integration, and family support in Latino college student persistence and health. Journal of Vocational Behavior, 59, 53-63.

Valentine, N. L. (1986). Factors related to attrition from doctor of education programs in the College of Human Resources and Education at West Virginia University (Doctoral Dissertation, WestVirginia University, 1986). Dissertation Abstracts International, 47 (406).

Valentine, N. L. (1987, May). Factors related to attrition from Doctor of Education programs. paperpresented at the annual forum of the Association of Institutional Research, Kansas City, MO. (ERIC Document Reproduction Service No. ED 293774).

Vaquera, G. (2008). Testing theories of doctoral student persistence at a Hispanic Serving Institution. Journal of College Student Retention, 9(3), 283-305.

Vilkinas, T. (2007). An exploratory study of the supervision of Ph.D. research students' theses. Innovative Higher Education, 32(5), 297-311. Doi:10.1007/s01755-9057-5. Retrieved from http://link.springer.com/10.1007/s10755-007-9057-5 
Wao, H. O., \& Onwuegbuzie, A. J. (2011). A mixed research investigation of factors related to time to the doctorate in education. International Journal of Doctoral Studies, 6, 115-134. Retrieved from http://ijds.org/Volume6/IJDSv6p115-134Wao320.pdf

Wasburn-Moses, L. (2008). Satisfaction among current doctoral students in special education. Remedial and Special Education, 29(5), 259-268.

\section{Biography}

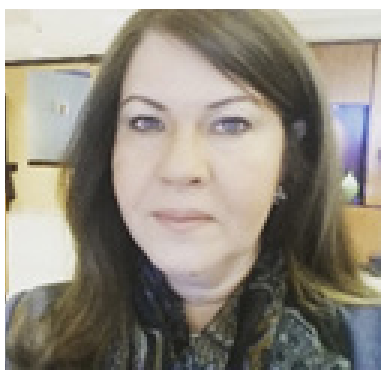

Dr. Floralba Arbelo Marrero, Assistant Professor of Education at Carlos Albizu, has had the privilege of teaching, developing educational programs, and collaborating with universities and NGO projects in Puerto Rico, Haiti, Cuba, Dominican Republic, and in the United States in the areas of teaching and learning, curriculum development, social justice research, distance education, nonprofit management, and grant writing. Research areas include Hispanic student success, Hispanic Serving Institutions, doctoral student retention, and online teaching and learning. Dr. Arbelo-Marrero has earned degrees from Brooklyn College of the City University of New York, The New School for Public Engagement, and a doctorate in Educational Leadership from Liberty University. Dr. Arbelo-Marrero is the recipient of the Women that Transcend Award for Global Leadership in Education and Community Service, and has presented her research at the Hispanic Association of Colleges and Universities, Association of Hispanics in Higher Education, Alliance of Hispanic Serving Institution Educators, and the National Association of Hispanic and Latino Studies. 